Artikel Penelitian

\title{
Analisa Produk Pola Cetakan Lilin yang Diproduksi Menggunakan DIY- CNC-Endmill
}

\author{
Firman Ridwan, Ryan Rahman \\ Jurusan Teknik Mesin, Fakultas Teknik, Universitas Andalas, Kampus Limau Manis, Padang 25163, Indonesia
}

INFORMASI ARTIKEL

Sejarah Artikel:

Diterima Redaksi: 07 Agustus 2018

Revisi Akhir: 24 September 2018

Diterbitkan Online: 29 Oktober 2018

KATA KunCI

Mesin CNC

Mesin CNC

End-Milling

KORESPONDENSI

E-mail: firmanridwan@ft.unand.ac.id

\section{A B S T R A C T}

The use of technology in ring jewelry manufacturers in Indonesia is still very limited. Ring jewelers still use traditional methods in the process of forming mold patterns. This causes difficulties in producing ring jewelry that requires precision and high accuracy on each product. Unprecised wax pattern of ring jewelry can result in dimensional errors when product is manufactured so the dimension is far from the size of the design. To avoid this, it can be overcome by using $\mathrm{CNC}$ machine technology. CNC machines can work consistently and precisely. For this reason, therefor, an End-Milling type CNC machines that has accuracy of up to $1 / 1000 \mathrm{~mm}$ is designed. The experiments showed that the results with high accuracy having standard deviation of repeatability of inner diameter 0.020736441 , repeatability of outer diameter 0.020493902 and repeatability of thickness 0.043817805 .

\section{PENDAHULUAN}

Perhiasan khususnya cincin tengah berkembang pesat di tengah-tengah pasar global saat ini, dimana trend permintaan pasar perhiasan cincin lebih dominan pada permintaan model desain, dibandingkan kuantitas ordernya [1]. Hal ini menuntut para desainer perhiasan cincin dapat membuat produk perhiasan cincin yang diterima pasar.

Faktanya produsen perhiasan cincin yang ada masih dapat dihitung dengan jari, itupun para desainernya masih mengandalkan pengalaman dalam proses produksinya, yang mana para desainer tersebut masih mengalami kesulitan dalam pembuatan produk dengan bentuk yang sama. Oleh karena itu untuk mendapatkan hasil produksi dengan keterulangan yang sama, maka perlu adanya teknologi dalam pembuatan perhiasan cincin.

Cincin dapat dibuat dengan metoda investment casting. Dari cara investment casting di atas, pembuatan sebuah pola merupakan proses yang paling penting dalam tahap-tahap pengecoran dikarenakan bentuk, dimensi, dan geometri dari pola sangat mempengaruhi dari hasil akhir produk. Pembuatan pola cetakan casting terbagi atas 2 jenis yaitu, secara konvensional atau tradisional dan secara modern. Pada cara tradisional proses pembuatan pola cetakan cincin masih menggunakan peralatan-peralatan yang sederhana dan dibuat langsung dari tangan pengrajin. Sedangkan cara modern yaitu proses penambahan atau pemotongan bahan baku menjadi sebuah pola menggunakan mesin yang dikendalikan oleh komputer. 
Mesin yang terkomputerisasi dapat membuat pola yang berulang dengan ukuran dan bentuk yang sama secara presisi. Salah satu peralatan modern yang dapat membuat pola ini adalah dengan mesin perkakas CNC (computerized numerical control). Mesin CNC dapat membuat pola perhiasan unik dan imajinatif, yang sulit dan bahkan tidak dapat dikerjakan hanya dengan keterampilan tangan pengrajin saja.

Dewasa ini pengrajin belum memiliki kemampuan untuk mengadopsi teknologi CNC untuk pembuatan pola dikarenakan beberapa hal, seperti (1) Mesin CNC khusus perhiasa sangat mahal. (2) Operator yang menjalankan CNC tidak banyak. Dengan alasan di atas pengrajin lebih cendrung membuat pola perhiasan dengan keterampilan tangan sehingga mehadapi masalah dengan repeatability.

Berdasarkan fakta di atas, maka penulis berinisiatif membuat mesin $\mathrm{CNC}$ sendiri untuk membuat pola perhiasan khususnya cincin yang memiliki ketelitian dan keterulangan yang terukur. Pembuatan pola lilin dapat dilakukan dengan cara pemotongan pada bahan baku pola searah seumbu $\mathrm{x}, \mathrm{y}$, dan $\mathrm{z}$ sesuai pola desain pada CAD (Computer-aided design), dan proses postprocessor pada CAM (Computer-aided manufacturing).

\section{METODOLOGI}

Skema tahapan perancangan dan pembuatan mesin CNC End-Milling dapat dilihat pada skema Gambar 1.

\subsection{Identifikasi Masalah}

Identifikasi masalah dalam penelitian ini dimulai dengan melihat kondisi di lapangan dimana proses pembuatan pola dari perhiasan cincin masih menggunakan cara tradisional atau konvensional. Oleh karena itu, untuk mendapatkan hasil produksi dengan keterulangan yang sama, maka perlu adanya mesin perkakas yang terkomputerisasi (CNC) dalam pembuatan pola pada perhiasan cincin.

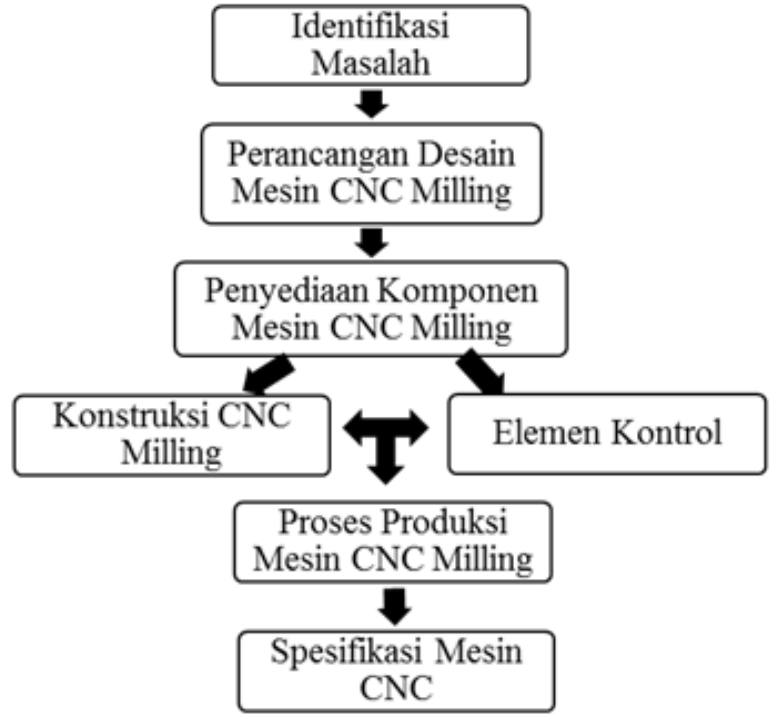

Gambar 1. Skema Perancangan dan Pembuatan Mesin CNC End-Milling

\subsection{Perancangan Desain Mesin CNC End- Milling}

Dari identifikasi terhadap masalah yang ditemukan di lapangan, maka dilakukan proses desain mesin CNC End-Milling yang dapat memproduksi pola untuk perhiasan cincin. Desain mesin CNC EndMilling dibuat dengan mempertimbangkan beberapa aspek seperti:

- Dimensi mesin CNC End-Milling

- Sistem penggerak

- Sistem transmisi

- Sistem kontrol

- Proses pemesinan yang akan dilakukan

- Komponen yang diperlukan

- Material pendukung

Desain perancangan dan perencanaan mesin CNC EndEnd-Milling secara solid dan isometrik dapat dilihat pada Gambar 2. 


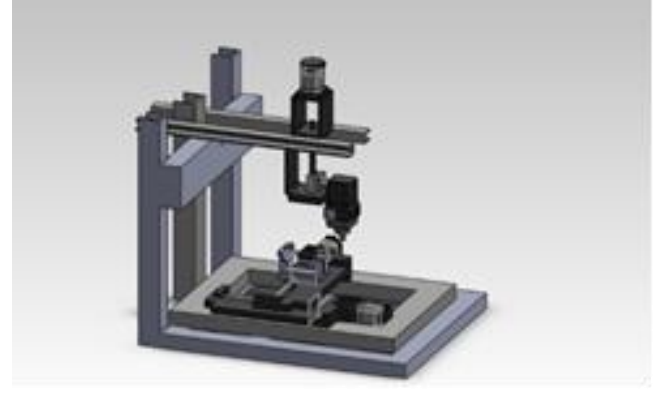

(a)

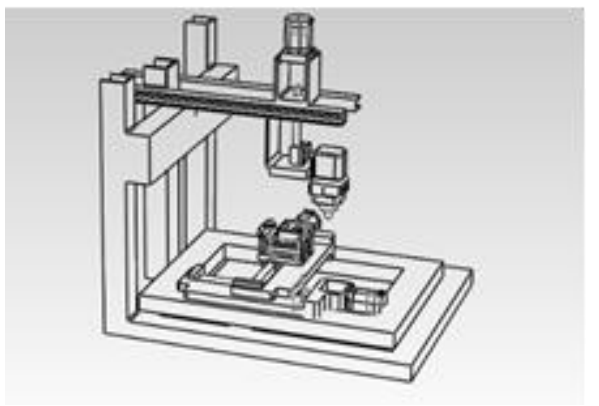

(b)

Gambar 2. Hasil Rancangan Mesin CNC End-EndMilling: (a) Rancangan Solid Mesin CNC EndEnd-Milling; (b) Rancangan Isomerik Mesin CNC

\subsection{Penyediaan Komponen Mesin CNC End- End-Milling}

Pemilihan komponen mesin CNC End-EndMilling sangat mempengaruhi kinerja dari mesin. Dalam perancangan mesin CNC End-EndMilling ada beberapa komponen penting dari mesin CNC yang perlu dipertimbangkan yaitu kegunaan dari komponen, ketangguhan komponen, dan ketersediaan komponen di pasar. Komponen yang akan digunakan pada mesin CNC End-EndMilling dapat dijelaskan sebagai berikut:

1. Tool

Tool pada mesin CNC End-End-Milling berfungsi sebagai pemotong yang akan berkontak langsung dengan benda kerja. Putaran Spindel menggunakan PCB drill atau bor mini sebagai motor pemutar pahat untuk memotong bagian benda kerja. PCB Drill memiliki tegangan $12 \mathrm{~V}$ DC dan meghasilkan putaran pahat sebesar 1400RPM, sehingga sudah cukup kuat untuk memotong lilin paraffin.
2. Motor

Motor yang akan digunakan sebagai penggerak sistem transmisi adalah motor stepper. Motor stepper yang digunakan adalah Vexta PK-569-A. Motor steper Vexta PK596-A memiliki putaran sudut terkecil sebesar $0.72^{\circ}$ dengan masukan arus sebesar 1.4 A/stepnya serta memiliki torsi sebesar 16 $\mathrm{Kg} / \mathrm{cm}$ sehingga motor stepper ini memiliki ketelitian yang cukup tinggi.

3. Driver motor

Driver motor merupakan suatu rangkaian khusus yang memiliki fungsi untuk mengatur arah ataupun kecepatan dari motor stepper. Driver motor yang dipilih sesuai dengan motor stepper PK-569 A adalah Super Vexta UDK5114N.

4. Transmisi

Transmisi yang digunakan untuk mesin sangat mempengaruhi ketelitian dari mesin tersebut. Pada umumnya mesin CNC menggunakan ball screw sebagai transmisi. Ball screw memiliki ketelitian yang tinggi dikarenakan gaya gesek yang terjadi sedikit lebih kacil dari pada lead screw.

5. Personal Computer (PC)

Dalam pengontrolan melalui PC dibutuhkan sebuah program yang digunakan untuk menjalankan G-Code pada mesin CNC. Program yang digunakan adalah Mach 3 yang kompatibel dengan Windows XP pada Microsoft dan EMC2 pada Linux.

6. Motion Kontrol Hardware

Motion Kontrol Hardware merupakan komponen yang berfungsi untuk mengkomunikasikan antara kontrol dengan aktuator serta memperkuat sinyal keluaran dari kontroler. Dalam perancangan element kontrol ini menggunakan motion kontrol hardware berupa Breakoutboard untuk mesin CNC 3 Axis.

\subsection{Konstruksi mekanik mesin CNC End-End- Milling}

a. Sumbu Z

Sumbu $\mathrm{Z}$ pada mesin CNC End-End-Milling berfungsi untuk mengatur naik turunnya tool 
atau mengatur kedalaman makan dari mesin. Tool digerakkan oleh motor stepper dan ditransmisikan oleh screw.

b. Sumbu Y

Sumbu Y pada mesin CNC End-Milling berfungsi untuk menggerakkan Meja Kerja kekiri dan kekanan.

c. Sumbu X

Sumbu X pada mesin CNC End-Milling berfungsi untuk menggerakkan komponen sumbu Y kedepan dan kebelakang.

d. Meja kerja

Meja kerja pada mesin CNC End-Milling berfungsi untuk letak benda kerja. Meja kerja dibuat untuk dapat mencengkram benda kerja sehingga kesalahan akibat pergeseran yang ditimbulkan akibat getaran selama proses produksi dapat diminimalisir.

\subsection{Elemen Kontrol}

Elemen kontrol pada Mesin CNC End-Milling digunakan untuk mengendalikan, memerintah, dan mengatur posisi dari sumbu axis mesin CNC. Proses pengkabelan elemen kontrol CNC EndMilling dapat dilihat pada skema Gambar 3.

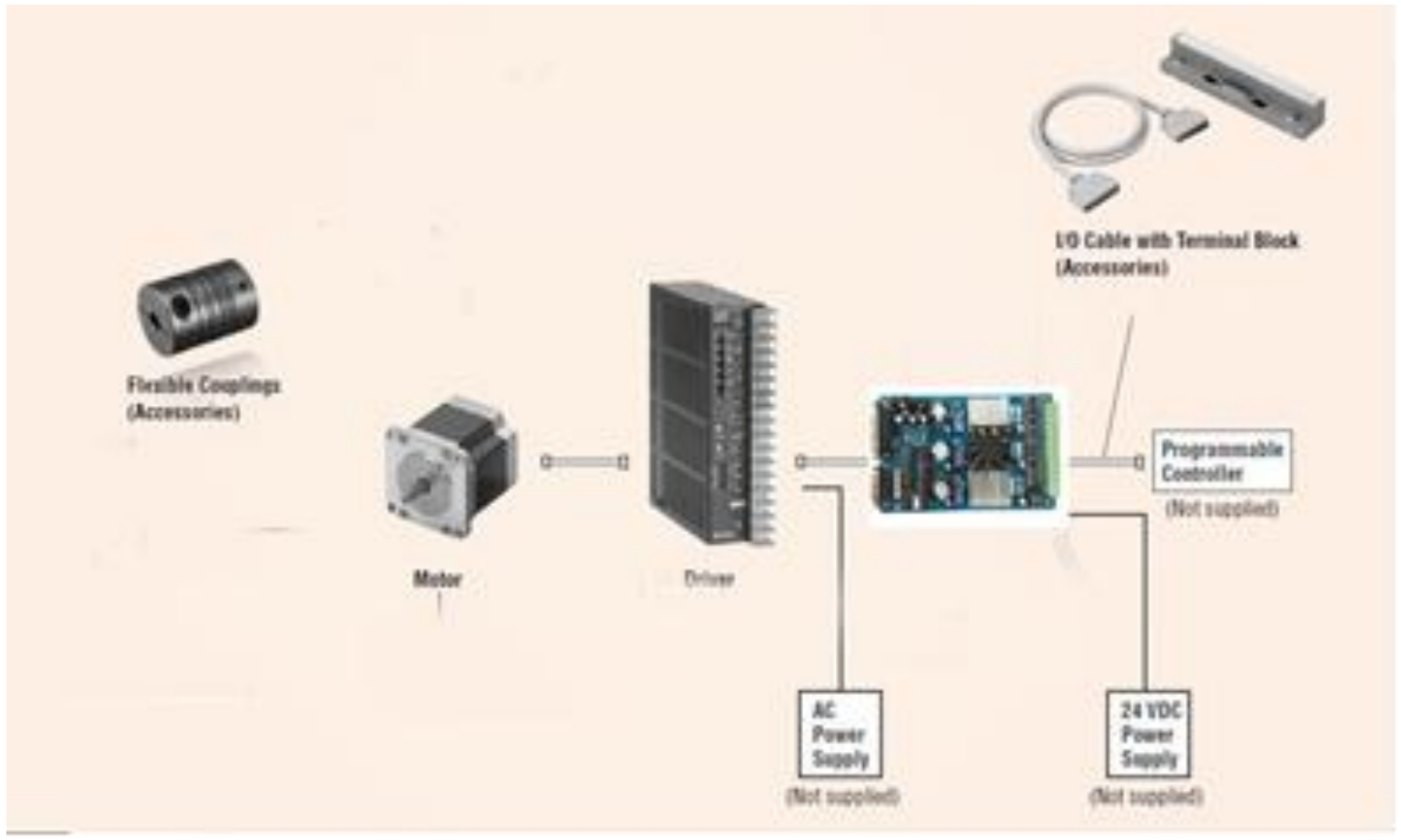

Gambar 3. Skema Wiring CNC End-Milling [15]

a. Programable control

Programable control yaitu menghubungkan interface perallel port pada komputer dengan motion kontrol hardware (Breakoutboard CNC MPI). Data yang dikirim software CAM bukanlah pulse dan arah (direction), melainkan data koordinat yang harus dituju menggunakan data biner.

b. Wiring Breakoutboard
Breakoutboard (BOB) adalah card electronic yang berfungsi menghubungkan sinyal data dari komputer dengan peripheral input maupun output. BOB merupakan komponen utama yang digunakan untuk merakit mesin CNC yang menghubungkan sinyal data dari komputer menuju driver atau relay. Skema koneksi wiring $\mathrm{BOB}$, power suplay dan driver vexta UDK5114 dapat dilihat pada Gambar 4. 


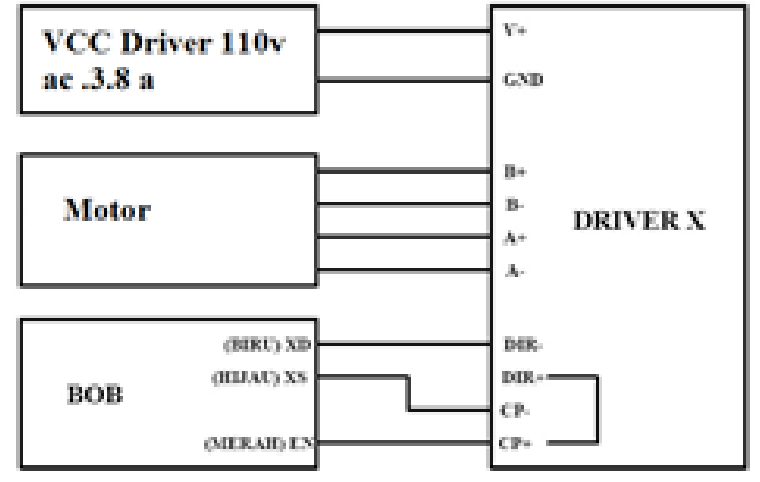

Gambar 4. Skema BreakoutBoard CNC MPI [15]

c. Wiring driver motor

Driver motor disini berfungsi sebagai kontroler. Sinyal dari komputer diterjemahkan oleh Breakoutboard kemudian driver motor mengolah data tersebut. Driver motor berfungsi sebagai otak dari sistem untuk kemudian sinyal tersebut diteruskan pada motor sebagai aktuator, sehingga dapat mengatur arah serta kecepatan putaran motor.

\subsection{Proses Produksi Mesin CNC End-Milling}

Proses produksi dilakukan untuk mewujudkan bentuk nyata dari perancangan yang telah ada. Pada perancangan mesin CNC End-Milling, proses produksi yang digunakan adalah proses pengelasan, perakitan batang dengan menggunakan baut dan pembuatan ulir dalam pada dasar kontruksi. Setelah pembangunan kontruksi mesin CNC End-Milling, selanjutnya adalah menggabungan antara mesin $\mathrm{CNC}$ dan elemen kontrol sesuai rangkaian skema yang ada sehingga mendapatkan spesifikasi dari mesin CNC EndMilling.

\subsection{Spesifikasi Mesin CNC End-Milling}

Spesifikasi dari mesin CNC End-Milling dibuat berdasarkan spesifikasi tiap komponen, perhitungan mendasar dan percobaan awal yang dilakukan untuk mendapatkan kinerja optimal dari mesin CNC End-Milling. Spesifikasi dari mesin CNC End-Milling secara kerseluruhan dapat dilihat pada Tabel 1.

Tabel 1. Spesifikasi Mesin CNC End-Milling

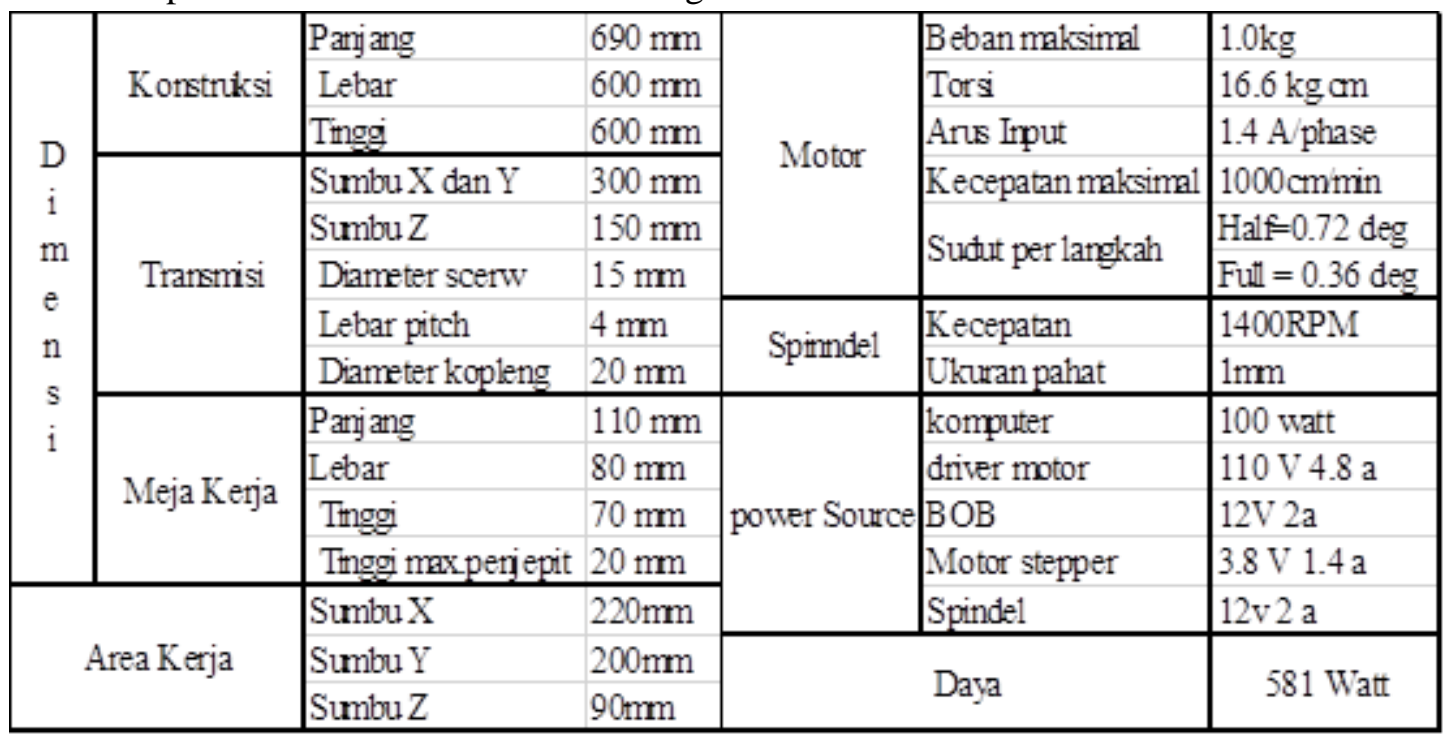




\section{HASIL DAN PEMBAHASAN}

Setelah penulis melakukan perancangan, pembuatan dan mengkalibrasi mesin CNC EndMilling, tahap selanjutnya adalah melakukan pengujian serta proses produksi pola cetakan cincin dari material lilin. Pengujian dilakukan untuk mengetahui ketepatan dan keterulangan dari mesin CNC End-Milling. Perhitungan mengenai ketepatan dan keterulangan dari mesin CNC EndMilling diperlukan agar mesin CNC End-Milling dapat dioperasikan dengan optimal.

\subsection{Pengujian Ketepatan dan Keterulangan Mesin CNC}

Pada pengujian ketepatan dan keterulangan ini, pahat (tool) pada mesin CNC End-Milling digantikan dengan pena. Sedangkan, benda kerja yang digunakan adalah kertas milimeter. panjang dari lintasan tool yang didapatkan dari pengujian diukur menggunakan jangka sorong.

\subsubsection{Desain Sampel Pengujian}

Desain sampel pengujian ketepatan berupa gambar garis lurus yang sejajar dengan sumbu $\mathrm{X}$ dan sumbu Y dengan panjang $20 \mathrm{~mm}$. Desain sampel pengujian ketepatan dapat dilihat pada Gambar 5.

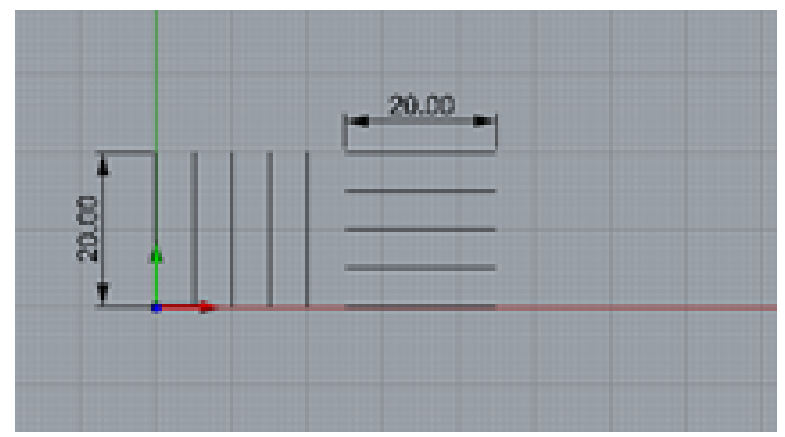

Gambar 5. Desain Sampel Pengujian Ketepatan

Desain sampel pengujian keterulangan berupa gambar persegi dan lingkaran.. Desain sampel pengujian keterulangan dapat dilihat pada Gambar 6.

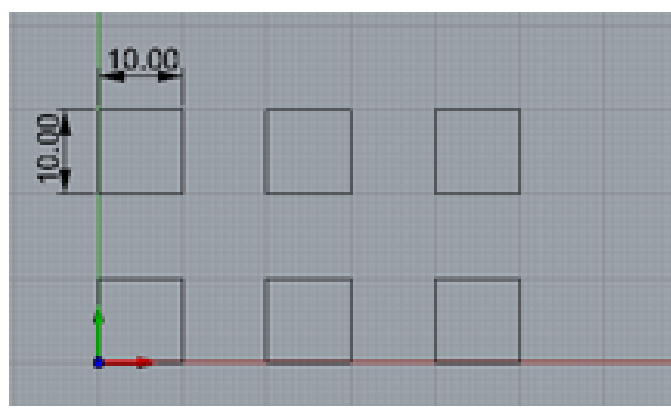

(a)

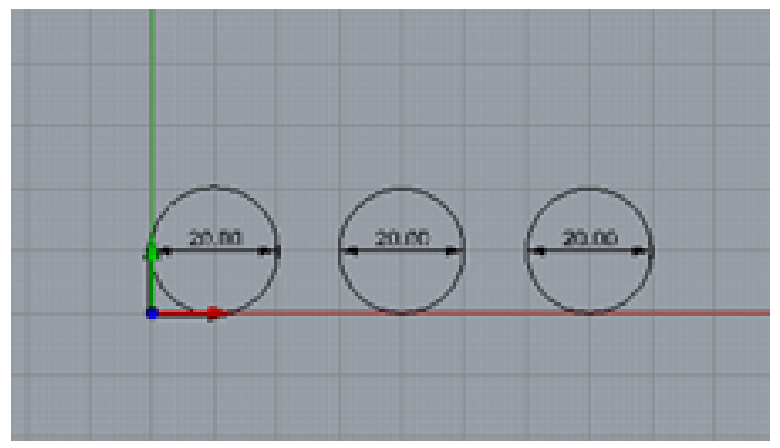

(b)

Gambar 6. (a) Desain Sampel Keterulangan Persegi dan (b) Desain Sampel Keterulangan Lingkaran

\subsubsection{Hasil Pengujian Sampel}

Karakteristik ketepatan dan keterulangan dari mesin CNC End-Milling yang didapatkan melalui pengujian sampel adalah sebagai berikut:

\section{Sampel untuk pengujian ketepatan}

Hasil pengujian ketepatan yaitu berupa garis lurus vertikal dan horizontal sebanyak lima garis pada masing-masing sumbu. Hasil pengujian ketepatan sumbu X dan Y dapat dilihat pada Gambar 7.

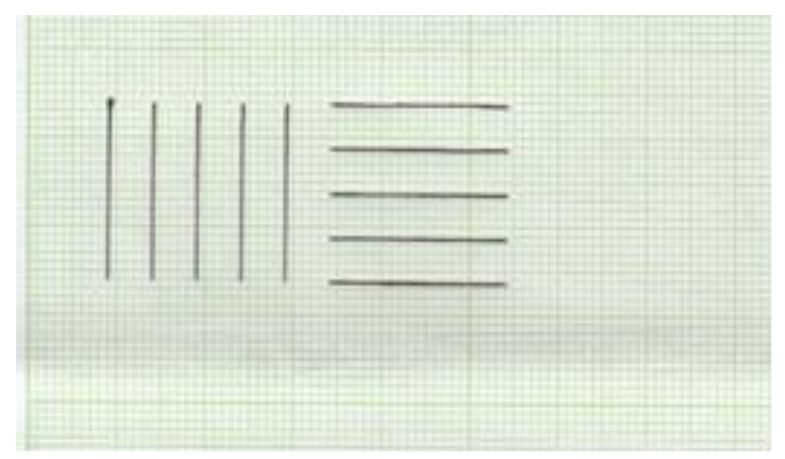

Gambar 7. Hasil Pengujian Vertikal dan Horizontal 
2. Sampel untuk pengujian keterulangan

Hasil pengujian keterulangan yaitu berupa gambar persegi dan lingkaran. Pengujian keterulangan dilakukan enam kali perulangan pada setiap sampel pengujian. Hasil pengujian keterulangan persegi dan lingkaran dapat dilihat pada Gambar 8 .

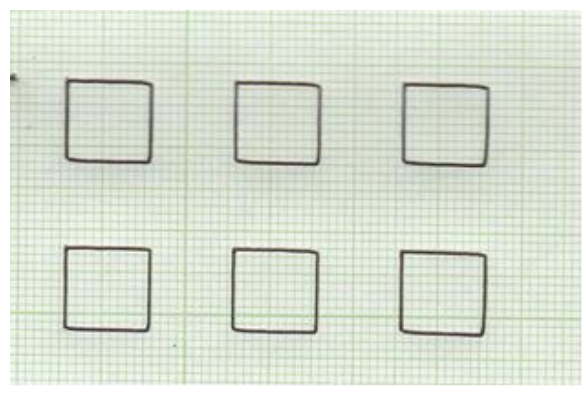

(a)

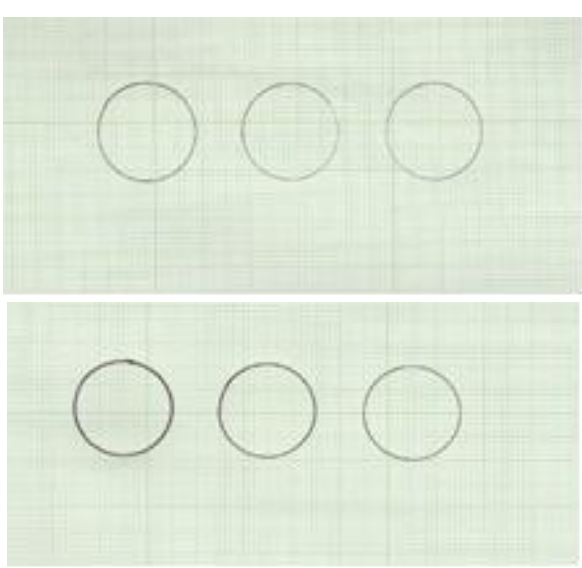

(b)

\subsubsection{Data Hasil Pengujian}

Gambar 8 memperlihatkan lintasan tool sesuai desain. Kemudian, lintasan tool diukur untuk memperoleh nilai ketepatan dan keterulangan dari mesin CNC End-Milling.Tujuan pengukuran ini adalah untuk membandingkan hasil nilai terukur pada gambar dengan nilai sebenarnya pada desain yang telah dibuat.

\section{Pengujian Ketepatan}

Pengujian ketepatan dilakukan untuk melihat nilai ketepatan sumbu X dan Y pada CNC End-Milling., Perhitungan ditentukan dengan mencari penyimpangan rata-rata dari nilai terukur terhadap nilai pada sampel atau disebut juga Standard Error (Se). Pada sumbu X didapatkan data pengukuran seperti yang dapat dilihat pada Tabel 2.

$$
\begin{aligned}
& S e=\sqrt{\frac{\mathrm{Se}}{n}} \\
& S e=\sqrt{\frac{0.016733201}{5}} \\
& \mathrm{Se}=0,0579
\end{aligned}
$$

Gambar 8. Hasil Pengujian Persegi dan Lingkaran

Tabel 2. Hasil Pengujian Ketepatan Sumbu X

\begin{tabular}{|c|c|c|c|c|}
\hline No. & $\begin{array}{c}\text { Ukuran } \\
\text { Sampel Desain } \\
(\mathbf{m m})\end{array}$ & $\begin{array}{c}\text { Ukuran Sampel } \\
(\mathbf{m m})\end{array}$ & $\begin{array}{c}\text { Penyimpangan (x) } \\
(\mathbf{m m})\end{array}$ & $\left(\mathbf{x}-\mathbf{x}_{\mathbf{r}}\right) \mathbf{2}(\mathbf{m m})$ \\
\hline 1 & 20 & 20 & 0 & 0.000256 \\
\hline 2 & 20 & 20 & 0 & 0.000256 \\
\hline 3 & 20 & 20.02 & 0.02 & $1.6 \mathrm{E}-05$ \\
\hline 4 & 20 & 20.02 & 0.02 & $1.6 \mathrm{E}-05$ \\
\hline 5 & 20 & 20.04 & 0.04 & 0.000576 \\
\hline \multicolumn{3}{|c|}{ Jumlah } & 0.08 & 0.00112 \\
\hline \multicolumn{3}{|c|}{ Rata-Rata } & \multicolumn{2}{c|}{0.016733201} \\
\hline
\end{tabular}

Nilai ketepatan mesin CNC End-Milling dapat dihitung dengan melihat besarnya standar deviasi dari hasil rata-rata perbandingan sampel pada persamaan (1). Nilai ketepatan mesin CNC EndMilling pada sumbu $\mathrm{X}$ adalah 0,0579 didapatkan dari perhitungan yang dilakukan terhadap hasil pengukuran pada sumbu $\mathrm{X}$, Pada sumbu $\mathrm{Y}$ didapatkan data pengukuran seperti yang dapat dilihat pada Tabel 3 . 
Tabel 3. Hasil Pengujian Ketepatan Sumbu Y

\begin{tabular}{|c|c|c|c|c|}
\hline No. & $\begin{array}{c}\text { Ukuran Sampel } \\
\text { desain }(\mathbf{m m})\end{array}$ & $\begin{array}{c}\text { Ukuran Sampel } \\
(\mathbf{m m})\end{array}$ & $\begin{array}{c}\text { Penyimpangan }(\mathbf{x}) \\
(\mathbf{m m})\end{array}$ & $\begin{array}{c}\left(\mathbf{x}-\mathbf{x}_{\mathbf{r}}\right) \mathbf{2} \\
(\mathbf{m m})\end{array}$ \\
\hline 1 & 20 & 20 & 0 & 0.000784 \\
\hline 2 & 20 & 20 & 0 & 0.000784 \\
\hline 3 & 20 & 20.02 & 0.02 & $6.4 \mathrm{E}-05$ \\
\hline 4 & 20 & 20.04 & 0.04 & 0.000144 \\
\hline 5 & 20 & 20.08 & 0.08 & 0.002704 \\
\hline \multicolumn{2}{|c|}{ Jumlah } & 0.14 & 0.00448 \\
\hline \multicolumn{2}{|c|}{ Rata rata } & \multicolumn{2}{c|}{0.028} \\
\hline
\end{tabular}

Dari persamaan (1) didapatkan bahwa nilai ketepatan sumbu Y adalah:

$S e=\sqrt{\frac{0.0334664011}{5}}$

$\mathrm{Se}=0,081812$

Nilai ketepatan mesin CNC End-Milling dapat dihitung dengan melihat standar deviasi dari ratarata hasil perbandingan sampel. Ketepatan sumbu $\mathrm{Y}$ adalah 0,081812 didapatkan dari perhitungan yang telah dilakukan terhadap hasil pengujian ketepatan sumbu Y.
2. Pengujian Keterulangan

Pengujian keterulangan dilakukan dengan cara membandingkan hasil pengukuran lintasan tool berupa lingkaran dan persegi dengan desain yang ada secara berulang atau disebut juga dengan Standard Deviasi (S). Dari hasil pengujian didapatkan data sebagai berikut:

\section{- Persegi}

Pengujian dilakukan dengan membandingkan ukuran hasil pengujian pada sisi sumbu $\mathrm{X}$ dan sumbu Y pada lintasan berbentuk persegi dengan ukuran $10 \mathrm{~mm}$. Hasil pengukuran dari keterulangan bentuk persegi dapat dilihat pada Tabel 4.

Tabel 4. Hasil Pengujian Keterulangan Persegi

\begin{tabular}{|c|c|c|c|c|c|c|c|c|c|}
\hline No. & $\begin{array}{c}\mathbf{X} \\
(\mathbf{m m})\end{array}$ & $\begin{array}{c}\mathbf{Y} \\
(\mathbf{m m})\end{array}$ & $\begin{array}{c}\text { Ukuran } \\
\text { Desain } \mathbf{x} \\
\text { dan y }\end{array}$ & $\begin{array}{c}\text { Penyimpang } \\
(\mathbf{x})(\mathbf{m m})\end{array}$ & $\begin{array}{c}\left(\mathbf{x}-\mathbf{x}_{\mathbf{r}}\right) \\
(\mathbf{m m})\end{array}$ & $\begin{array}{c}\text { Penyimpang } \\
(\mathbf{y})(\mathbf{m m})\end{array}$ & $\begin{array}{c}\left(\mathbf{y}-\mathbf{y}_{\mathbf{r}}\right) \\
(\mathbf{m m})\end{array}$ & $(\mathbf{x}-\mathbf{x r}) \mathbf{2}$ & $\left(\mathbf{y}-\mathbf{y}_{\mathbf{r}}\right)^{2}$ \\
\hline 1 & 9.9 & 9.9 & 10 & 0.1 & 0.072 & 0.1 & 0.05 & 0.005184 & 0.0025 \\
\hline 2 & 10 & 9.9 & 10 & 0 & 0.028 & 0.1 & 0.05 & 0.000784 & 0.0025 \\
\hline 3 & 10 & 10 & 10 & 0 & 0.028 & 0 & 0.05 & 0.000784 & 0.0025 \\
\hline 4 & 10.02 & 10 & 10 & 0.02 & 0.008 & 0 & 0.05 & 0.000064 & 0.0025 \\
\hline 5 & 10.01 & 10 & 10 & 0.01 & 0.018 & 0 & 0.05 & 0.000324 & 0.0025 \\
\hline 6 & 10.04 & 10.1 & 10 & 0.04 & 0.012 & 0.1 & 0.05 & 0.000144 & 0.0025 \\
\hline \multicolumn{3}{|c|}{ Jumlah } & 0.17 & & 0.3 & & 0.007284 & 0.015 \\
\hline \multicolumn{3}{|c|}{ Standar deviasi } & & & & & 0.038166 & 0.054772 \\
\hline
\end{tabular}

Nilai keterulangan ditentukan dari keragaman variabel yang diukur terhadap nilai rata-ratanya (standar deviasi). Perhitungan standar deviasi dilakukan pada setiap sumbu untuk melihat penyimpangan keterulangan persegi dari pengujian sampel. Perhitungan standar deviasi terhadap setiap sumbu adalah sebagai berikut: 
Sumbu X

$S=\sqrt{\sum_{k=1}^{n} \frac{\left(x-x_{r}\right)^{2}}{n-1}}$

$\mathrm{s}=0.038166$

\section{Sumbu $Y$}

Dari persamaan (2) didapatkan bahwa nilai keterulangan sumbu Y adalah:

$s=\sqrt{\frac{0.015}{5-1}}$

$\mathrm{s}=0.054772$
Dari perhitungan yang dilakukan dapat disimpulkan bahwa, tingkat keterulangan dari sumbu $\mathrm{X}$ memiliki deviasi 0,03 dan sumbu $\mathrm{Y}$ memiliki deviasi 0,05 .

\section{- Lingkaran}

Pengujian keterulangan dengan bentuk lingkaran bertujuan untuk melihat kemampuan mesin bergerak secara parabolik dengan mengkombinasikan gerakan pada sumbu $\mathrm{X}$ dan sumbu Y secara kontiniu dan bersamaan. Data hasil pengujian keterulangan untuk bentuk lingkaran dapat dilihat pada Tabel 5.

Tabel 2. Hasil Pengukuran Keterulangan Lingkaran

\begin{tabular}{|c|c|c|c|c|c|}
\hline No. & $\begin{array}{c}\text { Diameter } \\
\text { Desain }(\mathbf{m m})\end{array}$ & $\begin{array}{c}\text { Diameter Terukur } \\
(\mathbf{m m})\end{array}$ & $\begin{array}{c}\text { Penyimpangan (d) } \\
(\mathrm{mm})\end{array}$ & $\left(\mathbf{d}-\mathbf{d}_{\mathbf{r}}\right)(\mathbf{m m})$ & $(d-d r)^{2}$ \\
\hline 1 & 20 & 20 & 0 & 0.038333333 & 0.001469444 \\
\hline 2 & 20 & 20 & 0 & 0.038333333 & 0.001469444 \\
\hline 3 & 20 & 20.03 & 0.03 & 0.008333333 & $6.94444 \mathrm{E}-05$ \\
\hline 4 & 20 & 20.04 & 0.04 & 0.001666667 & $2.77778 \mathrm{E}-06$ \\
\hline 5 & 20 & 20.08 & 0.08 & 0.041666667 & 0.001736111 \\
\hline 6 & 20 & 20.08 & 0.08 & 0.041666667 & 0.001736111 \\
\hline \multicolumn{3}{|c|}{ Jumlah } & 0.038333333 & & 0.006483333 \\
\hline \multicolumn{3}{|c|}{ Standar Deviasi } & \multicolumn{3}{|c|}{0.036009258} \\
\hline
\end{tabular}

Penyimpangan dari keterulangan lingkaran dapat dilihat dengan menghitung standar deviasi dari hasil pengujian. Perhitungan standar deviasi keterulangan lingkaran adalah sebagai berikut:

Dari persamaan (2) didapatkan bahwa nilai keterulangan sumbu lingkaran adalah:

$s=\sqrt{\frac{0.00648}{6-1}}$

$\mathrm{s}=0.0360$

Dari perhitungan yang telah dilakukan, dapat disimpulkan bahwa untuk bentuk geometri lingkaran memiliki keterulangan dengan standar deviasi 0,0360 .

\subsection{Pembuatan Produk Pola Cincin}

Pembuatan produk pola cetakan cincin dilakukan setelah didapatkannya nilai ketepatan dan keterulangan dari mesin CNC End-Milling.

\subsubsection{Desain Produk Perhiasan Cincin}

Proses perancangan produk dengan menggunakan software CAD adalah hal pertama yang dilakukan sebelum melakukan proses produksi. Bentuk dan ukuran produk yang diinginkan bergantung dari proses peerancangan. Dalam desain produk pola cincin ini, ukuran dari produk yaitu berdiameter luar $23,5 \mathrm{~mm}$, diameter dalam $20 \mathrm{~mm}$ dengan ketebalan 3,5mm. Ukuran yang ditetapkan ini sudah mengacu dari hasil pengujian ketepatan dan keterulangan yang dilakukan sebelumnya. Gambar desain produk pola cincin dapat dilihat pada Gambar 9. 


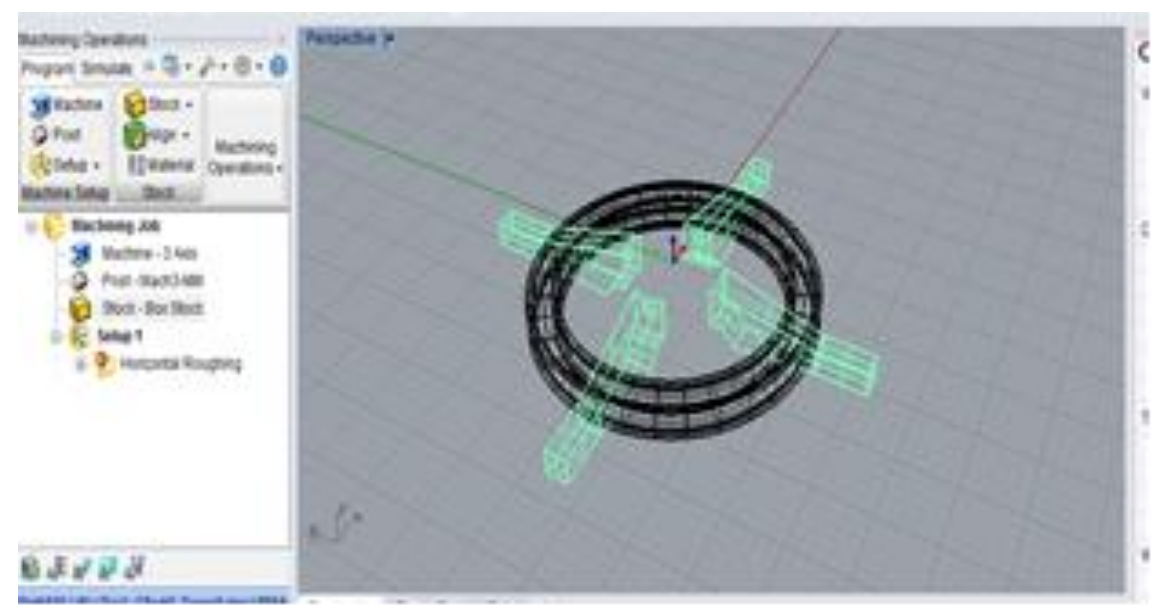

Gambar 9. Desain Produk Pola Cincin

\subsubsection{Hasil Produk}

Dari proses produksi pola cincin menggunakan mesin CNC End-Milling yang telah dilakukan, hasil proses produksi dapat dilihat pada Gambar 10.

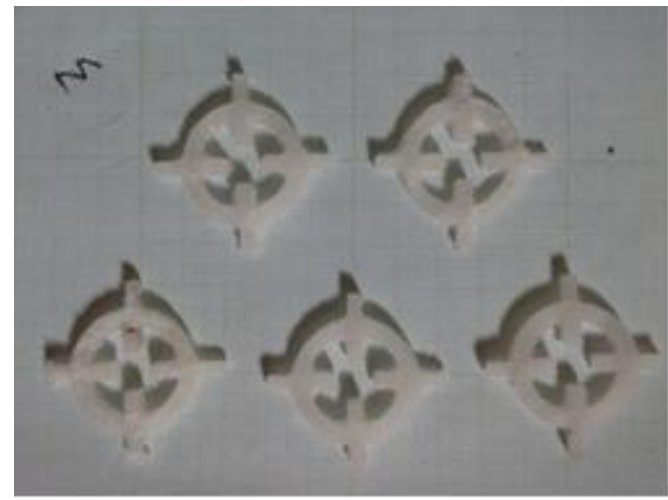

Gambar 10. Hasil Produksi Cetakan Cincin Keseluruhan

\subsubsection{Ketepatan dan Keterulangan Pola Cetakan Cincin}

Pengolahan data terhadap produk hasil mesin CNC End-Milling dihitung setelah dilakukannya proses produksi pola cetakan cincin menggunakan mesin CNC End-Milling. Disamping itu, tujuan pengolahan data tersebut berguna untuk melihat performa atau kinerja dari mesin yang telah dibuat.

\section{a. Perhitungan Ketepatan}

Tujuan perhitungan ketepatan adalah membandingkan ukuran desain dengan ukuran sebenarnya untuk parameter diameter luar, diameter dalam dan ketebalan.

- Ketepatan diameter dalam

Ketepatan dari diameter dalam produk pola cetakan perhiasan cincin dihasilkan melalui perhitungan terhadap hasil pengukuran produk. Dari persamaan (1) didapatkan bahwa nilai ketepatan diameter dalam adalah:

$$
\begin{aligned}
& S e=\sqrt{\frac{0,020736441}{5}} \\
& \mathrm{Se}=0,064399
\end{aligned}
$$

- Ketepatan diameter luar

Ketepatan dari diameter luar produk pola cetakan perhiasan cincin didapatkan dari perhitungan terhadap hasil pengukuran produk.

Dari persamaan (1) didapatkan bahwa nilai ketepatan diameter luar adalah:

$$
\begin{aligned}
& \text { Se }=\sqrt{\frac{0,020493902}{5}} \\
& \text { Se }=0,064022
\end{aligned}
$$

\section{- Ketebalan}

Ketepatan dari ketebalan produk pola cetakan perhiasan cincin didapatkan berdasarkan 
perhitungan terhadap hasil pengukuran produk searah sumbu Z.

Dari persamaan (1) didapatkan bahwa nilai ketepatan ketebalan adalah:

$$
\begin{aligned}
& S e=\sqrt{\frac{0,043817805}{5}} \\
& \mathrm{Se}=0,093614
\end{aligned}
$$

\section{b. Perhitungan Keterulangan}

Nilai dari keterulangan produk pola perhiasan cincin dapat ditentukan dari besar perbedaan nilai hasil pengukuran sampel dengan rata rata yang didapatkan atau disebut juga Standard Deviasi (S).

- Keterulangan diameter dalam

Keterulangan dari diameter dalam produk pola cetakan perhiasan cincin didapatkan dari membandingkan hasil pengukuran pada produk pola cetakan cincin dengan ukuran sebenarnya. Dari persamaan (2) didapatkan bahwa nilai keterulangan diameter dalam adalah:

$$
\begin{aligned}
& s=\sqrt{\frac{0,00172}{5-1}} \\
& \mathrm{~s}=0,020736441
\end{aligned}
$$

- Keterulangan diameter luar

Seperti halnya pada perhitungan keterulangan diameter dalam, perhitungan keterulangan dari diameter luar produk pola cetakan perhiasan cincin dihasilkan dari perhitungan terhadap hasil pengukuran produk.

$$
\begin{aligned}
& S=\sqrt{\frac{0,00168}{5-1}} \\
& S=0,020493902
\end{aligned}
$$

Dari hasil perhitungan standar deviasi dari luar dan diameter dalam didapatkan bahwa nilai simpangan rata-rata yang terjadi tidak begitu jauh berbeda. Hal ini menandakan, keterulangan produk searah sumbu $\mathrm{X}$ dan $\mathrm{Y}$ cukup baik.
- Keterulangan ketebalan

Sedangkan, Keterulangan dari ketebalan produk pola cetakan perhiasan cincin didapatkan dari perbandingan hasil pengukuran ketinggian produk atau searah sumbu $\mathrm{Z}$ dengan nilai yang sebenarnya.

$$
\begin{aligned}
& S=\sqrt{\frac{0,00768}{5-1}} \\
& S=0,043817805
\end{aligned}
$$

\section{ANALISIS}

Analisis mengenai mesin CNC End-Milling dan produk pola cetakan cincin didapatkan dari keseluruahan proses rancang bangun dan pengujian yang telah dilakukan. Mesin CNC End-Milling dapat bekerja sesuai fungsinya dimana pergerakan sumbu telah mengikuti pola alur dan membentuk produk sesuai dengan desain pada CAD. Serta, Mesin CNC End-Milling juga mampu mebentuk pola cincin secara otomasi dengan kecepatan dan kedalaman potong yang diinginkan. Akan tetapi, Mesin CNC End-Milling ini masih belum bisa dikatakan terstandarisasi melihat dari segi kepersisian dan keterulangan masih terdapat banyak kesalahan dibandingkan dari sebuah mesin CNC pabrikan. Kesalahan kesalahan (error) yang terjadi pada pengujian sampel dan proses produksi tersebut disebabkan oleh.

\section{Konstruksi Mesin CNC End-Milling}

Pembuatan dan perakitan mesin CNC End-Milling dilakukan tanpa didukung oleh peralatan yang memadai sehingga terlihat dibeberapa bagian terdapat kondisi pengelsan yang buruk, missalingment pada lubang dan baut, dan tidak adanya referensi dari kedataran mesin.

\section{Elemen kontrol Mesin CNC End-Milling}

Input sinyal yang masuk ke aktuator (motor stepper) tidak stabil yang menyebabkan lampu indikator $\mathrm{CW}$ dan $\mathrm{CCW}$ sering menyala secara bersamaan pada driver motor. Serta, hasil pengujian ketepatan mesin CNC yang semakin 
lama seiring waktu dan pertambahan laju temperatur pada driver semakin buruk dan berakibat pada perulangan pada hasil pengujian.

\section{KESIMPULAN}

Kesimpulan dari keseluruhan proses pembuatan mesin CNC ini adalah sebagai berikut. Dari keseluruhan proses rancang bangun, pengujian serta produksi pola cetakaan cincin dapat ditarik kesimpulan bahwa perangkat mesin CNC telah dapat bekerja dengan semestinya. Begitu juga dengan karakteristik pengujian mesin CNC yang diperlihatkan pada pengujian tool path dan karakteristik produk yang dihasilkan dari mesin CNC End-Milling.

\section{DAFTAR PUSTAKA}

[1] A. Indra,"Perancangan dan Perencanaan Mesin Selective Laser Sintering (SLS) Skala Laboratorium," Teknik Mesin. Universitas Andalas, 2012.

[2] http://www.custompartnet.com/wu/selectivelaser-sintering, diakses 26 Febuari 2015

[3] M.F.V.T. Pereira, M. Williams, W. B. Du Preez,"Application Of Laser Additive Manufacturing to Produce Dies For Aluminium High Pressure Die-Casting," South African Journal of Industrial Engineering. Stellenbosch University, 2012.

[4] E.P. Grenda, Castle Island Worlfwide Guide to Rapid Prototyping. http://www.additive3d.com/home.htm, diakses 17 Februari 2015.
[5] (http://mesincncbubut.wordpress.com/sejara h-perkembangan-mesin-cnc/), diakses 10 Desember 2014.

[6] E.P. Melky, A. Angga, "Aditif Manufacturing Rapid Prototyping”. Program Studi Magister Teknik Mesin, Pascasarjana Universitas Andalas, 2012.

[7] C.K, Chua, K.F. Leong and C.S Lim,"apid Prototyping: Principles and Applications. World Scientific Publishing Ltd, 2013

[8] F. Islami, "Rancang Bangun Prototype Mesin CNC Router", Teknik Mesin. Universitas Andalas, 2012.

[9] http://dir.indiamart.com/impcat/End-Millingmachines.html, diakses februari 2015

[10] http://trikueni-desainsistem.blogspot.com/2014/03/PengertianMotor-Stepper.html, diakses Juni 2014

[11] Tim Asisten. 2010. Laporan Akhir Praktikum Mekatronika. Teknik Mesin. Universitas Andalas.

[12] http://elektronika-dasar.web.id/teorielektronika/motor-servo/, diakses Juni 2014

[13] http://www.slideshare.net/Electromate/tolom atic-sls-mls-rodless-screw-drive-actuatorcatalog, diakses Februari 2015

[14] https://mutiamanarisa.wordpress.com/2010/0 9/30/program-dan-bagian-program-cnc/, diakses Februari 2015

[15] maxtron Persada. 2005. Manual books MPI Breakoutboard. Jakarta.

[16] Vexta mtors Inc. 2004. Motor Stepper Vexta UDK569 Reference Manual. Singapore.

[17] Vexta mtors Inc. 2004. Driver Motor Vexta UDK 5114 Reference Manual. Singapore.

[18] A.Nofriheldi, "Pembuatan Konstruksi dan Sistem Otomasi Mesin CNC Plasma Cutting," Teknik Mesin. Universitas Andalas, 2013. 